\title{
Die teks van die Bybel: Hermeneutiek, uitleg en interpretasie
}

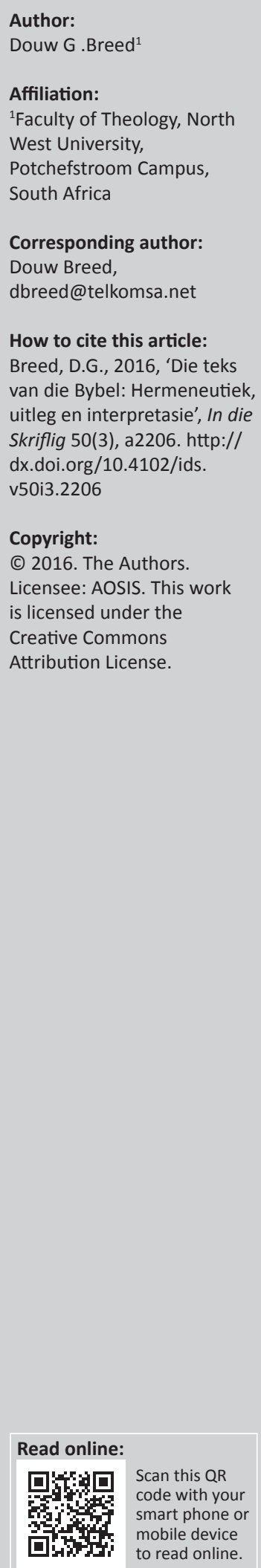

Prof. Dr. Gert Johannes Cornelis Jordaan het op 23 Februarie 2016 die ouderdom van 65 bereik die ouderdom waarop hy, volgens die ooreenkoms met die Noordwes-Universiteit (NWU), moet emeriteer. Jorrie, soos hy alom bekend staan, ontvang sy doktorsgraad in 1979 in Grieks met die proefskrif getiteld: 'Die beoordeling van woordorde-variante in die Evangelie volgens Lukas'.

Jorrie het 'n uitsonderlike geseënde loopbaan gehad. Reeds in 1979 word hy hoof van die Departement Grieks aan die destydse Potchefstroomste Universiteit van Hoër Onderwys (PU vir CHO). Nadat hy in 1982 as predikant bevestig is en in twee gemeentes gedien het, word hy in 1989 beroep om as professor in Nuwe Testament aan die Teologiese Skool Potchefstroom (TSP) en die Fakulteit Teologie van die PU vir CHO te dien. Hy dien vanaf 2004-2009 as vise-rektor van die TSP en in 2010-2015 as rektor.

Op die studieterrein van die Nuwe Testament het Jorrie oor die jare 'n besondere bydrae gelewer en hy geniet hoë aansien en erkenning by op nasionale sowel as internasionale gebied. Hy het op sy eie en in samewerking met ander kollegas dertien boeke, vyf hoofstukke in versamelbundels asook vier-en-twintig tydskrifartikels in vaktydskrifte gepubliseer. In 2011, 2012 en 2013 ontvang hy die NWU-toekenning as topdosent in die Fakulteit Teologie.

Jorrie se toewyding in diens van die Here blyk ook uit sy arbeid in die kerke - in besonder in die Gereformeerde Kerke van Suid-Afrika (GKSA). Hy het op verskeie deputate van die GKSA se Algemene Sinode gedien, word dikwels genooi om as spreker by kerklike byeenkomste op te tree en was vir etlike jare redakteur van Die Kerkblad, 'n publikasie van die GKSA. Die wye reeks onderwerpe van populêr-teologiese artikels wat uit Jorrie se pen verskyn het, toon sy kennis van en insig in God se Woord en sy vermoë om die Woord in die alledaagse lewe te kan toepas.

Ons is dankbaar dat Jorrie se kollegas positief gereageer het op die versoek tot 'n bydrae in die huldigingsbundel wat aan hom opgedra word. Hoewel daar nie in die beplanning van hierdie feesbundel gepoog is om bydraes rondom 'n geformuleerde tema te verkry nie, sou die tema: 'Die teks van die Bybel: hermeneutiek, uitleg en interpretasie' tog in 'n groot mate as samevattende tema kon dien.

Herculaas Frederik (Herrie) van Rooy ondersoek die gebruik van die boek Esegiël in die vier Evangelies, Handelinge, in die briewe van Paulus, in Hebreërs en die algemene sendbriewe. Hy bevind dat daar in hierdie korpus slegs twee duidelike aanhalings uit die boek Esegiël is, naamlik in 2 Korintiërs 6, maar dat daar wel 'n hele aantal heenwysings na die boek Esegiël is. Die aanhalings en heenwysings na Esegiël kan volgens Van Rooy meestal eerder verbind word aan die Griekse teks van Esegiël as aan die Masoretiese teks. Hy toon ook aan dat die twee aanhalings in 2 Korintiërs op 'n tipiese Pauliniese manier gebruik word as deel van 'n reeks aanhalings waarin die profetiese tekste gebruik word vir kontemporêre toepassings, maar waarin die oorspronklike konteks van die aanhalings nie soseer verreken word nie. Volgens Van Rooy speel die herdermetafoor in Esegiël 34 en 37 'n belangrike rol om Jesus as die (goeie) Herder uit te beeld.

D.F. Tolmie ondersoek die brief aan Filemon vanuit 'n forensiese perspektief en interpreteer die brief teen die destydse wetlike agtergrond. Hy aanvaar in sy ondersoek dat Onesimus Filemon se huis verlaat het om vir Paulus te vra om vir hom voorspraak te maak by Filemon. Tolmie bespreek Paulus se strategie teen die agtergrond van die destydse wetlike aspekte aangaande slawerny. Hy bevind dat Paulus in sy brief aan veel meer as slegs aan die wetlike vereistes voldoen het: hy was bewus van 'n belangriker soort geregtigheid, naamlik dié van God.

Jan A. du Rand beklemtoon dat elke deeltjie narratiewe inligting om 'n teks verstaanbaar te maak, belangrik is en handel in sy bydrae oor die doel van narratiewe 'tersydes' in die verhaal van die Openbaring. Hoewel hy erken dat 'n 'tersyde' in werklikheid ondefinieerbaar is, bied hy tog 
iets van 'n definiëring wanneer hy die Engelse 'asides' vertaal met 'voetnote' in die vertelteks of 'nie-regstreekse verwysings', 'syspraak', 'eenkant' en 'opsy' om die semantiese relevansie uit te druk. Du Rand gebruik die narratief van 4 Esra as 'vergelykbare en tydgenootlike literêre pool' tot 'n beter verstaan van die narratief van Openbaring. Hy bevind dat die tersydes beslis semantiese waarde aan sowel die gang as die inhoud van die Openbaringsnarratief toevoeg en dat dit narratologies funksioneel onontbeerlik is.

Francois P. Viljoen dui in sy bydrae die sentrale plek aan wat die Torah in die Evangelie volgens Matteus inneem. Volgens Viljoen beklemtoon Matteus dat Jesus geleer het dat die geldigheid van die Torah voortduur. Viljoen beweer dat Jesus se interpretasie van die Torah in Matteus van dié van die Fariseërs en die skrifgeleerdes verskil. Die geregtigheid wat Jesus volgens Matteus geleer het, verskil byvoorbeeld duidelik van die geregtigheid wat die Fariseërs en die skrifgeleerdes geleer het.

Paul Kruger ondersoek die seëninge wat aan die aartsvaders beloof is en hoe hierdie seëninge oorvloei na ander. Kruger bevind dat daar ' $n$ 'oorvloeiseën' is vir nasate wat nie deel van die verbondshooflyn vorm nie sowel as vir persone met wie die aartsvaders assosieer en vir vorste en konings van omliggende volke. Hy dui aan dat die aartsvaders שָׁלוֹם bewerk vir mense wat binne die invloedsfeer van die verbondsgeslag beweeg en trek ook sekere lyne deur na die latere profete en die Nuwe Testament.

Sarel P. van der Walt bestudeer in sy bydrae die mensbeskoulike en samelewingsteoretiese vertrekpunte van die Hebreërskrywer en neem Hebreërs 10:38-39 as vertrekpunt. Nadat hy aandag gegee het aan die bestaande antropologiese denke van die Grieks-Hellenistiese periode, dui Van der Walt aan hoe die openbarings-historiese inligting in Hebreërs 'n korrektief op die denkpatrone van daardie tyd bied en hoe die korrekte verstaan van die evangelie rigtinggewend vir samelewingsteoretiese vertrekpunte is.

H.G.L. (Eric) Peels toon in die bestudering van Jeremia 46:2-12 aan dat Jeremia in 46:2 na die slag van Karkemis in 605 v.C. verwys. Om Jeremia se profetiese interpretasie van die gebeure te verstaan, doen Peels kontekstuele eksegese van die perikoop en verstaan hy die perikoop in sy literêre konteks en teen sy historiese agtergrond. Nadat hy kortliks die struktuur- en detaileksegese van 46:10 aangebied het, dui hy die besondere bedoeling en betekenis van die gedeelte aan: God maak in sy universele heerskappy 'n einde aan die magswellus. Hy laat nie die verwoesting waarvan in 46:6 sprake is sonder straf verbygaan nie.

Gert Breed ondersoek die diens van die ouderling. Hy gee in besonder aandag aan 1 Petrus 5:1-5 en die gebruik van die diakon woordgroep in 1 Petrus. Nadat hy die plek van 1 Petrus 5 binne die hele brief ondersoek het, nagegaan het wat die verband tussen 1 Petrus 5:1-4 en 1 Petrus 4:7-1 is en detaileksegese van 1 Petrus 5:1-4 gedoen het, kom hy tot die gevolgtrekking dat Petrus in 1 Petrus 5:1-4 die diakonia van ouderlinge beskryf. Op grond van hierdie navorsing, stel hy sekere riglyne aan die diakonia van die ouderling volgens 1 Petrus voor.

Raymond Potgieter maak dit duidelik in sy artikel dat Anna Reinhard Zwingli se lewensverhaal verweef is met die ontwikkeling van die Reformasie in Zurich en die invloed wat dit op haar en haar gesin gehad het. Hy toon aan dat die reformasiegeskiedenis nie deeglik weergegee kan word sonder om aandag te gee aan die plek wat merkwaardige vroue in daardie tyd ingeneem het nie. Potgieter kom tot die gevolgtrekking dat, alhoewel die Reformasie betekenisvolle veranderinge vir vroue teweeg gebring het, dit geneig was om voorskriftelik te word. Hy wys daarop dat die rol van vroue tot vandag toe ' $n$ omstrede saak in die Christelike kerk bly.

Cynthia L. Miller-Naudé \& Jacobus A. Naudé kom tot die gevolgtrekking dat die Bybel deur mondelinge tradisie sowel as geskrewe aktiwiteit saamgestel is. Terwyl hulle gebruik maak van die insigte van en debatte oor die terrein van Biblical performance criticism, stel hulle 'n genuanseerde beskrywing voor van die verwantskap tussen die mondelinge en geskrewe kultuur in die sosiale wêreld van die Bybel. Hulle beklemtoon dat hierdie twee aspekte nie kronologies of ten opsigte van belangrikheid ten volle geskei kan word nie. Die twee aspekte kan egter ook nie buite rekening gelaat word vir die beskrywing van 'n samehangende model van die bybelse media-geskiedenis nie. In die lig hiervan gee Miller-Naudé en Naudé ' $n$ interpretasie en vertaling van die woorde $\beta i \beta \lambda$ íov en $\beta i ́ \beta \lambda$ os.

Jan van der Watt gee in sy artikel aandag aan die oorinterpretasie van tekste in gevalle waar daar moontlike verwysings na ander tekste is. Hy besin spesifiek oor die intertekstuele verwysing na Genesis 28 (die JakobBet-El-verhaal) en hoe dit die interpretasie van Johannes 1:51 interpretatief beïnvloed en of hierdie interpretasies reg laat geskied aan die verstaan van 1:51. Hy beskou 1:51 as 'n sleutelteks in Johannes en aanvaar dat die interpretasie daarvan konsekwensies het vir die verstaan van die res van die Evangelie - veral vir die Christologie en engeleleer. Aan die einde van die artikel maak Van der Watt enkele metodologiese opmerkings oor die interpretasie van ' $n$ teks en die vereistes en grense wat deur die teks self gestel word.

Carel F.C. Coetzee gee in sy artikel eerstens eervolle erkenning aan die werk wat Jorrie Jordaan op die terrein van die gereformeerde hermeunetiek gedoen het. Hy spits hom tweedens toe op die hermeneutiek van die belydenisskrifte. Hy beklemtoon die noue verbinding tussen die Skrif en die belydenisskrifte, en die gevolglike gesag van die belydenisskrifte. Coetzee wys daarop dat dit belangrik is om in gedagte te hou dat, hoewel die belydenisskrifte as sodanig reeds verklaring en gesagvolle kommentaar op die Skrif is, die belydenisskrifte self ook op hulle beurt verklaar moet word. Hy gee 'n aantal riglyne wat toegepas behoort te word met die oog op die korrekte verstaan en verklaring van die belydenisskrifte. 